\title{
Analysis of Land Availability and Needs with Potential Agricultural Land-Development Within Santan Watershed and Marangkayu, East Kalimantan
}

\author{
Akhmad Sopian ${ }^{1}$ Sigit Hardwinarto ${ }^{2}$ Muhammad Sumaryono ${ }^{3}$ \\ Marlon Ivanhoe Aipassa ${ }^{2 *}$ \\ ${ }^{I}$ Agrotechnology Study Program of Widya Gama Mahakam University Jl.K.H Wahid Hasyim, Sempaja Samarinda \\ 75124 \\ ${ }^{2}$ Laboratory of Soil and Water Conservation, Faculty of Forestry, Mulawarman University Campus of Gn. Kelua Jl. \\ Penajam Samarinda 75119, East Kalimantan, Indonesia \\ ${ }^{3}$ Laboratory of Forest Planning, Faculty of Forestry, Mulawarman University Campus of Gn. Kelua Jl. Penajam \\ Samarinda 75119, East Kalimantan, Indonesia \\ *Corresponding author. Email: marlon.ivanhoe@gmail.com
}

\begin{abstract}
The development of population at the Santan watershed area over the years tends to increase, increasing the food and settlement needs. Therefore, there is a need to balance the needs and availability of land. The study aims to determine the potential of agricultural land by assessing land availability based on soil types and patterns of regional space. The descriptive quantitative method based on LH Ministerial Regulation No. 17 of 2009 is used as the study method. Land obtained that the study area has diverse availability and land requirements where only Muara Kaman sub-district has a surplus status. In contrast, Sangata Selatan, Teluk Pandan, Bontang Selatan and Marangkayu sub-districts have deficit status. Types of land in potential research areas for the development of food crops and horticulture commodities. Potential areas for developing the agricultural area, namely the Marangkayu sub-district, are in cultivation areas, while Bontang Selatan, Muara Kaman, South Sanggata, and Teluk Pandan are in non-cultivation areas. The plantation area pattern and settlement pattern was not following the carrying capacity, which was on the slope of $>40 \%$, while the protected forest area was on the slope of $<26 \%$. Making the spatial pattern should be adjusted to the carrying capacity of the environment.
\end{abstract}

Keywords: Availability, Potential Agricultural Land, Watershed

\section{INTRODUCTION}

In human activities and daily life, the land is part of the environment as a natural resource that has a significant role in humans' various interests. The land used, among others, for settlement, agriculture, livestock, mining, roads and buildings, social, economic facilities and so on. Increasing population causes the area of cultivated land to be smaller, which causes the increasing population pressure on the land. Then in shifting cultivation, the increase in population density also increases population pressure on land because of the increased need for food due to the shortening of the land leftovers period [1].
There is pressure on land at the Santan watershed area due to the increasing population and the operating several coal mining companies in three sub-districts: Teluk Pandan, Marangkayu and Bontang Selatan. Land usage is a structure and pattern planned and unplanned, including inventory, designation and maintenance. The principle of land stewardship is based on all interests in an integrated, efficient and successful manner, harmonious, harmonious, balanced and sustainable. The main problem in regulating land usage is the need for land to continue to increase. In contrast, cultivated land is very limited in availability - the demand for land due to increasing population. The increasing population will increase development activities together with the growing need for land. Another consequence of the 
increase in population is the transfer of land functions, which impacts the lack of food production in an area.

Regulatory policies are carried out through zoning arrangements with land usage in line with spatial plans [2]. The physical approach is carried out by analyzing land capability's suitability on actual land usage and spatial planning patterns [3]. The land economic approach has been carried out by calculating the economic value generated by each land-use class. The analytical method used based on the Minister of Public Works Regulation No.20/PRT/M/2007 concerning Technical Guidelines for Physical \& Environmental Analysis [4].

This study used a method of environmental carrying capacity based on the Minister of Environment Regulation No. 17 of 2009 and regional spatial patterns. The procedure of environmental carrying capacity was carried out by analyzing the needs and availability of land by assessing land usage suitability based on regional spatial patterns.

\section{METHODS}

This study used the exploratory method by describing an object of study. The reason for choosing this study was to describe the condition of land availability at the Santan watershed. Data included maps of soil types, population, crop production, fruits and plantations. Data on this type of land was obtained by field surveys, interviews and statistics in East Kutai, Bontang and Kutai Kartanegara Regencies.

\subsection{Carrying Capacity of Agricultural Land}

Determining the carrying capacity of agricultural land using formulas from the combined concepts of the theories of Odum, Christeiler, Ebenzer Howard and Issard adopted by [5] in [6], namely:

Where;

$\sigma=$ level of carrying capacity of agricultural land

$X=$ Harvest area of food crops per capita

$\mathrm{K}=$ Land area for food self-sufficiency

Furthermore, the values of $\mathrm{X}$ and $\mathrm{K}$ can be determined using the formula below:

$$
\mathrm{X}=\frac{\text { Harvest area }}{\text { Total Population }}
$$

$$
\mathrm{K}=\frac{\mathrm{KFM}}{\text { Production }}
$$

Areas capable of food self-sufficiency can meet the minimum physical needs (KFM) of 1,600 calories/person/day, equivalent to $265 \mathrm{~kg}$ of rice/person/year. In comparison, the area that can provide a decent life for the population is equal to 650 $\mathrm{kg}$ of rice/person/year or 2,466 times of KFM [5]. From this value, the classification of the carrying capacity of agricultural land can be determined as presented in Table 1.

Table 1. Classification of Agricultural Land Carrying Capacity

\begin{tabular}{ccl} 
Class & $\begin{array}{c}\text { Agricultural Land } \\
\text { Carrying Capacity }\end{array}$ & \multicolumn{1}{c}{ Information } \\
\hline I & $\sigma>2.47$ & $\begin{array}{l}\text { Areas capable of self-sufficiency in food and able to provide a decent life for the } \\
\text { population } \\
\text { II }\end{array}$ \\
Areas that are capable of self-sufficiency in food but have not been able to \\
III
\end{tabular}

\subsection{Optimum Population Amount}

Based on the formula of carrying capacity of agricultural land can be determined by the optimum population (OP) according to the results of food crops in the five sub-districts in the Santan watershed, namely;

$\mathrm{OP}=$ DDL $\mathrm{x}$ Population

\section{RESULTS AND DISCUSSION}

\subsection{Agricultural Land Carrying Capacity}

The status of agricultural land carrying capacity was determined to the status of land carrying capacity at the level of food self-sufficiency. Food self-sufficiency was determined by calculating harvested areas for commodities such as rice, corn, soybeans, peanuts, green beans, soybeans, cassava and sweet potatoes. Self-sufficiency status in the five sub-districts is presented in the following Table 2. 
Table 2. Supporting Capacity of Food Crops in Five Districts at Santan Watershed

\begin{tabular}{rlccrrr}
\hline No & Sub-district & $\begin{array}{c}\text { Number of } \\
\text { Population }\end{array}$ & $\begin{array}{c}\text { Harvest Area } \\
\text { (ha) }\end{array}$ & $\begin{array}{c}\text { Production } \\
\text { (rice kg) }\end{array}$ & $\begin{array}{c}\text { DDL } \\
\text { Agriculture }\end{array}$ & $\begin{array}{r}\text { Optimal } \\
\text { Population }\end{array}$ \\
\hline 1 & Sangata Selatan & 22,731 & 348 & $1,549,000$ & 0.192 & $4,356.01$ \\
2 & Teluk Pandan & 15,253 & 492 & $2,347,000$ & 0.336 & $5,319.13$ \\
3 & Muara Kaman & 20,385 & 3605 & $19,252,000$ & 2.143 & $43,677.78$ \\
4 & Bontang Selatan & 71,748 & 67 & 432,442 & 0.012 & 871.26 \\
5 & Marangkayu & 31,614 & 2,915 & $16,370,000$ & 1.276 & $37,353.24$ \\
\hline
\end{tabular}

The results of the analysis carried out at Santan watershed area showed Muara Kaman and Marangkayu sub-districts with carrying capacity in the range of $1 \leq \sigma$ $\leq 2.47$ including in class II, which means that this area was capable of self-sufficiency in food but had not been able to provide a decent life for its people. In contrast, the districts of South Sangata, Teluk Pandan and Bontang Selatan had the carrying capacity in the range of $\sigma<1$, including in-class III, which mean that this area had not been able to self-sufficient food. The environmental environment's carrying capacity in the study area showed South Sangata, Teluk Pandan and Bontang Selatan had not been able to self-sufficient food.
The decrease in land carrying capacity was influenced by the population, the decreasing land area, the percentage of the number of farmers and the area of land needed, and the types of commodities in the local area [7]. Food crop production is not proportional to the population; therefore, it is necessary to increase the harvest area to support the population. While the Muara Kaman and Marangkayu Districts, the harvest area is still sufficient to support the people, although they have not provided a decent life for them. Of the five subdistricts, only the Muara Kaman sub-district has an optimum population of 43,677 people > an entire population.

Table 3. Carrying Capacity of Agricultural Land Based on Soil Type and Slope of Santan Watershed

\begin{tabular}{|c|c|c|c|c|}
\hline \multirow{2}{*}{ No } & \multirow{2}{*}{$\begin{array}{c}\text { Type of soil } \\
\text { Research Area }\end{array}$} & \multicolumn{2}{|c|}{ Slope } & \multirow[b]{2}{*}{ Grand Total } \\
\hline & & $<2 \%$ & $2-8 \%$ & \\
\hline \multirow[t]{2}{*}{1} & Bontang Selatan & & 204.60 & 204.60 \\
\hline & Eutropepts & & 204.60 & 204.60 \\
\hline \multirow[t]{7}{*}{2} & Marang Kayu & $10,664.51$ & $12,830.09$ & $23,494.60$ \\
\hline & Dystropepts & & - & - \\
\hline & Eutropepts & - & $9,710.62$ & $9,710.62$ \\
\hline & Hydraquents & 446.71 & & 446.71 \\
\hline & Sulfaquents & 421.06 & & 421.06 \\
\hline & Tropohemists & $9,796.74$ & & $9,796.74$ \\
\hline & Tropudults & & $3,119.47$ & $3,119.47$ \\
\hline \multirow[t]{2}{*}{3} & Sangatta Selatan & & 173.31 & 173.31 \\
\hline & Eutropepts & & 173.31 & 173.31 \\
\hline \multirow[t]{4}{*}{4} & Teluk Pandan & 396.14 & $5,832.48$ & $6,228.62$ \\
\hline & Eutropepts & & $5,832.48$ & $5,832.48$ \\
\hline & Tropohemists & 396.14 & & 396.14 \\
\hline & Grand Total & $11,060.65$ & $19,040.48$ & $30,101.13$ \\
\hline
\end{tabular}

Based on the type of soil and slope, the potential for developing agricultural land in the Bontang area is 204.60 ha. In the Marangkayu area, the land had a slope of $<2 \%$, that is $10,664.51$ ha, soil type was hydraquents with an area of 446.71, sulfaquents area is 421.06 ha, and tropohemist area is $9,796.74$ ha, these three types of soil are inundated, suitable only for plants wetland rice with water management. The types of eutropepts in Bontang Selatan, Marangkayu, Sanggata Selatan and 
Teluk Pandan were potential for the development of secondary crops. Eutropepts soil type was quite fertile because it was located in the valley area, on the land could be developed rice fields if sufficient water was available. In Marangkayu District, there was a type of tropudults with an area of 3,119.97 ha. This type of land could develop dryland agriculture such as corn, soybeans, peanuts, green beans, sweet potatoes, and cassava. This type of soil was also suitable for upland rice.

\subsection{Land Usage in the Santan Watershed Area}

Land usage in fisheries that are not suitable is settlements, mining, dryland agriculture, and rice fields. Plantation areas include mining, dryland agriculture, rice fields and ponds. Residential areas have no settlements, but there are plantations, plantations, mining, dryland agriculture, rice fields and ponds. There are mining, dryland agriculture, rice fields, and ponds in the Food Crops and Horticulture Zone. Land use in the Santan Watershed area pattern is presented in Table 3.

Table 4. Patterns of Spatial Areas with Land Cover in Five Districts of Santan Watershed

\begin{tabular}{|c|c|c|c|c|c|c|}
\hline No. & Land cover & $\begin{array}{c}\text { Fisheries } \\
\text { area }\end{array}$ & Plantations & Settlement & $\begin{array}{c}\text { Food crops and } \\
\text { horticulture }\end{array}$ & $\begin{array}{l}\text { Grand } \\
\text { total }\end{array}$ \\
\hline 1 & Swamp swamp & $1,386.76$ & 39.45 & 169.03 & 537.39 & $2,132.63$ \\
\hline 2 & Secondary dryland forest & & $3,618.43$ & 3.80 & & $3,622.23$ \\
\hline 3 & Secondary mangrove forest & 204.16 & & 5.00 & 34.05 & 243.21 \\
\hline 4 & Secondary swamp forest & & 0.02 & & 73.97 & 73.99 \\
\hline 5 & Plantations & & $5,694.06$ & 575.15 & 5.63 & $6,274.84$ \\
\hline 6 & Settlement & 3.05 & & & & 3.05 \\
\hline 7 & Plantation & & $3,550.50$ & 637.09 & & $4,187.59$ \\
\hline 8 & Mining & 0.41 & 414.45 & 300.31 & 9.66 & 724.83 \\
\hline 9 & Dry land agriculture & 93.91 & 52.24 & 116.89 & 78.99 & 342.03 \\
\hline 10 & Mixed dry land agriculture & 185.99 & 557.17 & $1,012.68$ & $1,294.23$ & $3,050.07$ \\
\hline 11 & Swamp & - & & 2.19 & 148.67 & 150.86 \\
\hline 12 & Rice fields & 69.65 & 98.36 & 61.61 & 236.65 & 466.27 \\
\hline 13 & Shrubs & 921.60 & $9,816.05$ & $2,505.27$ & $2,017.64$ & $15,260.56$ \\
\hline 14 & Ponds & $1,316.99$ & 0.26 & 46.37 & 37.72 & $1,401.34$ \\
\hline 15 & Open land & 228.81 & 431.32 & 835.54 & 75.12 & $1,570.79$ \\
\hline & Grand Total & $4,411.33$ & $24,272.31$ & $6,270.93$ & $4,549.72$ & $39,504.29$ \\
\hline & Appropriate designation & $29,80 \%$ & $14,62 \%$ & $0 \%$ & $30,18 \%$ & \\
\hline
\end{tabular}

The area is designated as a cultivation area, namely 39,504.29 ha, divided into fisheries, plantations, settlements, food crops, and Horticulture. Land usage is mostly unsuitable for its use, and cultivated areas are swamp forests, secondary forests, mangrove forests, and settlements. Fisheries areas that fit space are $29.80 \%$, plantations $14.62 \%$, Food Crops and Horticulture $30.18 \%$. On land designated as fisheries, plantations and settlements, there are mines, fields and shrubs. The area of shrubs is quite large, namely $15,260.56$ ha; this land can increase agricultural land where the allocation of food crops and horticulture is 2,017.64 ha. In contrast, the potential land for plantation development is $9,816.05$ ha. The high land requirements in the districts of South Sanggata, Bontang Selatan and Teluk Pandan are more significant than the availability of land, so the population's tendency to open new land in the form of forests.

\subsection{Study of Space Patterns on the Potential of Agricultural Development}

Five sub-districts located at the Santan Sungai Basin area, a potential area for the development of agricultural land, namely Marangkayu District. Bontang Selatan Subdistrict, Muara Kaman, and Teluk Pandan spatial patterns established by the government, namely the designation of protected forests, conversion production forests, and natural reserve areas. 
Table 5. Patterns of the Five Sub-District Spaces in the Santan and Marangkayu Watershed Areas

\begin{tabular}{|c|c|c|c|c|c|c|}
\hline \multirow{2}{*}{$\begin{array}{l}\text { Space Pattern } \\
\text { Sub-District }\end{array}$} & \multicolumn{5}{|c|}{ Slope } & \multirow[b]{2}{*}{ Grand Total } \\
\hline & $<2 \%$ & $2-8 \%$ & $16-25 \%$ & $26-40 \%$ & $>40 \%$ & \\
\hline Bontang Selatan & & 204.60 & 406.31 & & 197.79 & 808.70 \\
\hline - Protection Forest & & 166.68 & 257.46 & & 151.37 & 575.51 \\
\hline - Conversion Production Forest & & 8.08 & 97.98 & & & 106.06 \\
\hline - Plantations & & 27.51 & 50.87 & & 46.42 & 124.80 \\
\hline - Settlement & & 2.33 & & & & 2.33 \\
\hline Marangkayu & $10,659.14$ & $12,830.09$ & $37,124.25$ & $11,280.53$ & $13,858.76$ & $85,752.77$ \\
\hline - Protection Forest & 137.26 & $1,240.40$ & 380.83 & & 57.29 & $1,815.78$ \\
\hline - Conversion Production Forest & 565.74 & 844.46 & 269.65 & & $1,229.41$ & $2,909.26$ \\
\hline - Permanent Production Forest & 154.54 & $6,301.41$ & $22,868.55$ & $7,768.01$ & $4,630.84$ & $41,723.35$ \\
\hline - Fisheries Area & $4,206.37$ & 204.96 & & & & $4,411.33$ \\
\hline - Plantations & $1,786.33$ & $1,374.69$ & $10,296.08$ & $3,434.01$ & $7,183.62$ & $24,074.73$ \\
\hline - Settlement & 879.69 & $1,657.29$ & $2,896.52$ & 78.51 & 756.59 & $6,268.60$ \\
\hline - Food crops and Horticulture & $2,929.21$ & $1,206.88$ & 412.62 & & 1.01 & $4,549.72$ \\
\hline Muara Kaman & & & 602.79 & 366.94 & 15.47 & 985.20 \\
\hline - Permanent Production Forest & & & 598.38 & 366.94 & 11.63 & 976.95 \\
\hline - Nature Reserve area & & & 4.41 & & 3.84 & 8.25 \\
\hline Sangatta Selatan & & 173.31 & 900.98 & 773.11 & $1,631.93$ & $3,479.33$ \\
\hline - Nature Reserve area & & 173.31 & 900.98 & 773.11 & $1,631.93$ & $3,479.33$ \\
\hline Teluk Pandan & 396.14 & $5,832.48$ & $16,410.17$ & $10,206.24$ & $30,373.89$ & $63,218.92$ \\
\hline - Protection Forest & 315.95 & 227.54 & 245.76 & & $7,121.37$ & $7,910.62$ \\
\hline - Conversion Production Forest & 68.83 & 487.55 & & & & 556.38 \\
\hline - Permanent Production Forest & & $4,511.51$ & $11,785.68$ & $7,018.81$ & $16,362.60$ & $39,678.60$ \\
\hline - Nature Reserve area & & 605.45 & $4,378.72$ & $3,187.43$ & $6,867.01$ & $15,038.61$ \\
\hline - Plantations & 11.36 & 0.43 & 0.01 & & 22.91 & 34.71 \\
\hline Grand Total & $11,055.28$ & $19,040.48$ & $55,444.50$ & $22,626.82$ & $46,077.84$ & $154,244.92$ \\
\hline Persentase & $7 \%$ & $30 \%$ & $36 \%$ & $15 \%$ & $12 \%$ & \\
\hline
\end{tabular}

Bontang Selatan Subdistrict area was not potential because most of the area was Protected Forest and Conversion Production Forest, while the allocation as plantation land was only 124.80 ha. The area of Muara Kaman and Sangata Selatan Districts was for permanent production forests and natural reserve areas. Teluk Pandan Subdistrict was mostly designated as Protected Forest, Permanent Production Forest, and Nature Reserve while the allocation as Plantation land is only 34.71 ha.

In the Marangkayu region, the allocation of agricultural food and horticulture crops was 4,549.72 ha, plantation land was $24,074.73$ ha, and the fishery area was $4,411.33$ ha. However, this area was suitable for developing food crops and horticulture agriculture in slopes $<16 \%$ with an area of 4,136.09 ha. At slopes $>$ $16 \%$, if managed for agricultural land, could cause erosion and landslides. The contribution of each parameter in the assessment of the flow coefficient which has the greatest to the smallest influence in the flow coefficient is the slope which influences $35.39 \%$, then vegetation cover of $25.25 \%$, infiltration of $22.86 \%$ and finally the flow density, which contributes $16.70 \%$ [7].

Based on Law No. 26 of 2007 concerning spatial planning, the preparation of regional spatial planning must consider the environment's carrying capacity and capacity. The pattern of space made in the study area did not match the environment's carrying capacity. The land allocated for plantations and settlements in Marangkayu District was at a slope of $>25 \%$. Allotment of Protection Forest was on slopes <25\% in Bontang Selatan sub-districts, Marangkayu, South Sanggata and Pandan Bay. The criteria for protected forests had slopes of $>45 \%$, had an altitude of $2,000 \mathrm{~m}$ above sea level, hydro-orological purposes that regulated the water 
system to prevent floods and erosion and maintain the durability and fertility of the soil $[8,9]$.

\section{CONCLUSION}

Types of land in research areas is potential for the development of food crops and horticulture commodities. Potential land for agricultural land development, namely Marangkayu Subdistrict, were in cultivation areas while Bontang Selatan, Muara Kaman, South Sanggata, and Teluk Pandan were in noncultivated areas. The plantation area and the settlement did not match carrying capacity, which was on the slope of $>40 \%$, while the protected forest area was on the slope of $<26 \%$.

\section{ACKNOWLEDGMENTS}

Thank you to the DIRJEN DIKTI for funding this research through the 2012 Post Graduate Scholarship Scholarship. Thank you also to the East Kutai Regency Government, Kutai Kartanegara Regency, and East Kalimantan BPDAS, who gave the author permission to conduct research.

\section{REFERENCES}

[1] O. Soemarwoto, Ekologi, Lingkungan Hidup dan Pembangunan, Jakarta, 2001.

[2] E. Syahadat, Sylviani, Policy of Green Open Space Utilization of Regencies and Cities: Case Study in Banten Province, E-Jurnal Analisis Kebijakan Kehutanan, 13(2), 2016.

[3] M.M. Fahimuddin, B. Barus, S. Mulatsi, Carrying Capacity Analysis of Land in Baubau City, Southeast Sulawesi Province, Jurnal Tata Loka, 18(3), 2016.

[4] R. Ridha, N.U. Vipriyanti, I.A. Wiswasta, Analisis Daya Dukung Lahan sebagai Pengembangan Fasilitas Perkotaan Kecamatan Mpunda Kota Bima Tahun 2015-2035, Jurnal Wilayah dan Lingkungan, 4(1), 2016.

[5] Suhardjo, Tukiran, Studi Literatur Konsep yang Sudah Ada Mengenai Daya Tampung Wilayah. Kantor Menteri Negara Kependudukan dan Lingkungan Hidup, Jakarta, 1990.

[6] R.B. Vicki, Moniaga, Analisis Daya Dukung Lahan Pertanian, Jurnal ASE. 7(2), 2011, pp. 6168.

[7] I.W. Susanto, Analisis Daya Dukung Lingkungan Sektor Pertanian Berbasis Produktivitas di Kabupaten Bangli, Jurnal Bumi Lestari, 13(1), 2013.
[8] S. Hardjowigeno, Ilmu Tanah, Akademika Pressindo, Jakarta, 2007.

[9] S. Hardjowigeno, Evaluasi Kesesuaian Lahan dan Perencanaan Tata Guna Lahan. Gadjah Mada University Press, Yogyakarta, 2011.

[10] A. Miardini, T. Gunawan, S.H. Murti, Kajian Degradasi Lahan Sebagai Dasar Pengemdalian Banjir di DAS Juwana, Majalah Geografi Indonesia, 30(2), 2016. 